○加藤幸弘・猪瀬智哉・中村克己 飯島 渉・清水孝明

われわれは，胸部高王撮影時における被写体からの散 乱線除去による画質の向上と被曝線量の低減について, cross grid と他の grid の物理的性能を, JISZ一-4910に基 づき管電压 $140 \mathrm{kV}$ 一定とし蛍光量計法とフィルム法の 2 つの方法で求め比較検討した。その結果, $90^{\circ} \mathrm{Cross}$ grid50 cross grid, $12: 1 \mathrm{Al}$ grid, micro fine grid $の$ 順となり，cross gridが上位となった。

特に $90^{\circ}$ cross gridにおいては, コントラスト改善能：

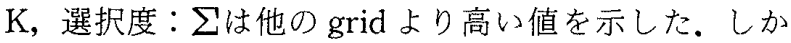
し, 露出倍数：Bがやや劣るため，K， $\mathrm{B}$ 性能を維持 し，Bを下げることにより，画質の向上と被曝線量の低 減を計ることが必要である。

\section{9. 足関節撮影法の画法幾何学的考察と整位}

立正佼成会附属佼成病院

○葉山和弘・神田幸助・渡辺雅弘

〔目的〕足関節の整位は，脛骨・腓骨・距骨の位置関 係の解析に役立つものでなければならない。よって，幾 何学的に正投撮されることが重要であり，その最適手法 を求めるために画法幾何学的検討を加え，整位がとれな い場合に抒いても，歪みのない正投影像を得る方法につ いて考察し, 日常臨床に応用し，良好な結果を得たので 報告する。

〔結果〕足骨節の整位として「底屈 $80^{\circ}$ 内外果の中央 を通る線をフィルムに水平とし，足部は自然肢位をとる」 が最も良好である。が，外側距腿関節勒带を観察したい 場合は，この基本整位より，5内旋する必要がある.

40. 分解能と頭蓋内 DSA について

東邦大学医学部附属大橋病院放射線部

○宮崎 茂・高田聖子・丸山 誠 松谷一雄

静注法による頭蓋内 DSA は左右の内頸, 椎骨動脈が 同時に造影されるため，左右同時に比較できる利点はあ るが，血管の重なりにより読影が困難な場合がある。そ こでDSAの分解能をX X 線テストチャートで, 管電圧, 光学絞りについて測定した，管電圧変化による分解能は 管電任が高くなる程レスポンスは低下する，光学絞りで は絞りが開く程レスポンスは低下する。今回測定した空 間分解能は管電圧，光学絞りに左右されず $1 \mathrm{LP} / \mathrm{mm}$ で あり，限界に近いものであった。頭蓋内DSA は分離能の 面からは主幹動脈，ウイリス輪の読影は可能であるが血 管が非常に接近してきたり，重なり合っている場合，現 在の分解能では識別不可能と考える。
41. 高感度システムの使用目的における考察

済生会横浜书南部病院

○林 幸一・佐野常晴・河内千代子 板橋慎二・鈴木靖晴・中野博美

蕗 利彦・有賀康城

〔目的〕希土類蛍光体は，X線被曝軽隇には有用であ るが，画質の点で劣ることがいわれている，新乳剤のオ ルソ系フィルムをテストする機会を得たので，その有用 性を報告する。

〔結果〕各システムとの MTFでは TMGOC が良い。 経験 1 年〜20年，10名の放射線技師のハウレットチャー トで画質評価をしたものでは，TMGは良く OC は低い. $80 \mathrm{kV} \sim 140 \mathrm{kV}$ での散乱線の影響を比較したとき $\mathrm{TMG}$ は最も少なかった。

(まとめ) 今回入手し，テストした TMGは，物理 的, 臨床的にも評価は良いが，OCについては特異性があ り，検討の必要がある。クロスオーバを施した TMG は，今迄のフィルムと比較しても評価が良く被曝軽減か らも従来のオルソフィルムのイメージを転換する必要が ある。

\section{2. 撮影条件管理のためのトータルシステム}

埼玉県立がんセンター放射線部 X 線診断

矢部 仁

従来，X 線撮影をする上で増感紙・フィルム・グリッ ド・X 線装置相互間の関係は，複雑で条件を管理するの は大変面倒であった。われわれはパーソナルコンピュー 夕の導入により，これらのデー夕を総合管理し撮影条件 を迅速かつ正磪に求めるシステムを考案した。

フィルムの特性曲線は，チェビシェフ Q 関数による多 項式近似法により表わし，X線の透過率についてはモデ ル式を用いて表わした。

今回は特に腹部単純撮影をモデルにして，実験には水 ファントムを使用し測定したデータにより撮影条件とし た。

43. マルチフォーマットの写真の心血管画像への応用 防衛医科大学校病院放射線部

$\bigcirc$ 新井畺二・山岡育雄・阿久沢比呂志 竹下 亨

今回，われわれは，マルチフォーマット写真の心血管 画像への応用を検討した。本法は, シネ撮影時の I.I. カメ ラ信号を DF 用のVDRに録画し，プロセッサにより画 像処理を行って，マルチフォーマットカメラで撮影する 方法である、また，VTR 録画像をVDR にダビングする ことにより，VTR 像からも同様な処理が可能である。 